\title{
Management of Takotsubo Syndrome: A Comprehensive Review
}

\author{
Yasar Sattar $^{1}$, Kelvin Shenq Woei Siew ${ }^{2}$, Michael Connerney ${ }^{1}$, Waqas Ullah ${ }^{3}$, M Chadi Alraies ${ }^{4}$ \\ 1. Internal Medicine, Icahn School of Medicine at Mount Sinai, New York, USA 2. Cardiology, University of Malaya, \\ Kuala Lumpur, MYS 3. Internal Medicine, Abington Hospital - Jefferson Health, Abington, USA 4. Cardiology, Detroit \\ Medical Center, Detroit, USA
}

Corresponding author: Yasar Sattar, sattary@nychhc.org

\begin{abstract}
Takotsubo syndrome (TTS), also known as Takotsubo cardiomyopathy, is a transient left ventricular wall dysfunction that is often triggered by physical or emotional stressors. Although TTS is a rare disease with a prevalence of only $0.5 \%$ to $0.9 \%$ in the general population, it is often misdiagnosed as acute coronary syndrome. A diagnosis of TTS can be made using Mayo diagnostic criteria. The initial management of TTS includes dual antiplatelet therapy, anticoagulants, beta-blockers, angiotensin-converting enzyme inhibitors or aldosterone receptor blockers, and statins. Treatment is usually provided for up to three months and has a good safety profile. For TTS with complications such as cardiogenic shock, management depends on left ventricular outflow tract obstruction (LVOTO). In patients without LVOTO, inotropic agents can be used to maintain pressure, while inotropic agents are contraindicated in patients with LVOTO. In TTS with thromboembolism, heparin should be started, and patients should be bridged to warfarin for up to three months to prevent systemic emboli. Our comprehensive review discussed the management in detail, derived from the most recent literature from observational studies, systematic review, and meta-analyses.
\end{abstract}

Received 12/26/2019

Review began 01/01/2020 Review ended 01/02/2020 Published 01/03/2020

\section{() Copyright 2020}

Sattar et al. This is an open access article distributed under the terms of the Creative Commons Attribution License CC-BY 3.0., which permits unrestricted use, distribution, and reproduction in any medium, provided the original author and source are credited.
Categories: Cardiac/Thoracic/Vascular Surgery, Cardiology, Internal Medicine Keywords: takotsubo cardiomyopathy, takotsubo syndrome, cardiomyopathy, left ventricular outflow tract obstruction, acute coronary syndrome

\section{Introduction And Background}

Takotsubo syndrome (TTS), also commonly known as Takotsubo cardiomyopathy or apical ballooning syndrome, is characterized by transient left ventricular (LV) wall dysfunction triggered by physical or emotional factors with similar presentation features as acute coronary syndrome (ACS) [1]. TTS accounts for $0.02 \%$ of the inpatient admission in the United States [2]. The prevalence of TTS in the general population, mimicking ST-segment elevation myocardial infarction (STEMI), is estimated to be $0.5 \%$ to $0.9 \%$, with a higher prevalence in women in their sixth decade of life. Indeed, $2 \%$ to $3 \%$ of STEMI presentations in women turn out to be TTS every year [2-4].

As the clinical presentation of TTS is often indistinguishable from ACS, it is a diagnosis of exclusion once true ACS is ruled out with coronary angiography. According to Luscher and Templin et al., TTS and ACS commonly present with chest pain and dyspnea on exertion [1,5]. However, most cases of TTS have an identifiable risk factor of physical or emotional stress that can differentiate it from ACS. To date, there is no noninvasive test that can confirm the diagnosis of TTS. The definitive diagnostic tool to differentiate TTS from ACS is coronary angiogram. Furthermore, an LV angiogram has classic features which include apical rounding, followed by basal and mid-ventricular contraction. Upon establishing the diagnosis, continuous telemetry monitoring and repeated echocardiograms are essential to identify complications of TTS. Some of the complications of severe TTS that can affect ionotropic function include acute heart failure, LV outflow tract obstruction (LVOTO), cardiogenic shock, and the presence of LV thrombus. Other complications of TTS can include rhythm abnormalities such as atrial fibrillation, ventricular fibrillation, atrioventricular block, and cardiac arrest [5]. Our review discusses current management approaches for TTS during the acute and long-term phases of the disease.

\section{Review}

\section{Literature search and data source}

A systematic search was performed on PubMed, MEDLINE, Cochrane Library, and Google Scholar databases. The search included MeSH terms for 'Takotsubo Cardiomyopathy', 'Takotsubo Syndrome', 'Broken Heart Syndrome', 'Stress Cardiomyopathy’, 'Transient Apical Ballooning Syndrome’, 'Apical Ballooning Syndrome’, ‘'Left Ventricular Apical Ballooning Syndrome', 'Treatment', and 'Management'. The MeSH terms were combined using Boolean operators AND and OR. The studies included were from inception to July 31, 2019. Inclusion criteria were studies that are in English language or foreign languages that are translated into English, and articles that are focused on the management of TTS with measurable outcomes. Exclusion criteria were single case reports and management with no measurable outcomes or follow-up. Two 
physicians conducted a literature search and independently screened all titles and abstracts. A total of 4,313 articles were found of which 248 articles met the inclusion criteria. Based on predefined criteria, only 16 of these articles were included in this review (Table 1) [5-20].

\begin{tabular}{|c|c|c|c|c|}
\hline $\begin{array}{l}\text { Authors, } \\
\text { Year of } \\
\text { Publication }\end{array}$ & $\begin{array}{l}\text { Study } \\
\text { Design: } \\
\text { Number of } \\
\text { Subjects (n), } \\
\text { Area of Study }\end{array}$ & Treatment Regimen & $\begin{array}{l}\text { Primary Measure Studied } \\
\text { and Follow-Up Duration }\end{array}$ & Study Outcomes and Conclusions \\
\hline $\begin{array}{l}\text { Templin et } \\
\text { al. } 2015\end{array}$ & $\begin{array}{l}\text { Retrospective } \\
\text { observational } \\
\text { study: } \\
\mathrm{n}=1,750 \text { (all } \\
\text { TTS) }\end{array}$ & Beta-blockers and ACE & $\begin{array}{l}\text { Outcome measure: MACE. } \\
\text { Follow-up: } 30 \text { days and } 10 \\
\text { years }\end{array}$ & $\begin{array}{l}\text { Study outcome: ACE inhibitor or ARB improve one- } \\
\text { year survival. Conclusion: ACE or ARB is beneficial, } \\
\text { beta-blockers not beneficial }\end{array}$ \\
\hline $\begin{array}{l}\text { Santoro et } \\
\text { al. } 2017\end{array}$ & $\begin{array}{l}\text { Prospective } \\
\text { cohort study: } \\
\mathrm{n}=12, \mathrm{TTS} \\
\text { with LV } \\
\text { thrombi }\end{array}$ & $\begin{array}{l}\text { Acute phase (in hospital): } \\
\text { LMWH followed by } \\
\text { enoxaparin. Long term: } \\
\text { OAC (warfarin) for } 3 \\
\text { months, discontinuation } \\
\text { upon resolution of TTS }\end{array}$ & $\begin{array}{l}\text { Outcome measures: Acute: } \\
\text { cerebrovascular embolic } \\
\text { event. Long term: new event } \\
\text { of stroke, overall survival. } \\
\text { Follow-up: } 984 \text { days }\end{array}$ & $\begin{array}{l}\text { Study outcomes: Acute phase: LMWH beneficial in } \\
\text { stroke prevention. Long term: interruption of OAC } \\
\text { after three months with no new stroke, similar } \\
\text { survival with or without LV thrombi. Conclusions: } \\
\text { LMWH beneficial in acute phase, OAC reasonable } \\
\text { use as stroke prophylaxis up to three months }\end{array}$ \\
\hline $\begin{array}{l}\text { Marfella et } \\
\text { al. } 2016\end{array}$ & $\begin{array}{l}\text { Randomized } \\
\text { controlled } \\
\text { trial: } \mathrm{n}=48 \text { (all } \\
\text { TTS) }\end{array}$ & ALA $600 \mathrm{mg}$ OD vs placebo & $\begin{array}{l}\text { Outcome measures: } \\
\text { quantitative MIBG imaging } \\
\text { for adrenergic cardiac } \\
\text { innervation improvement; } \\
\text { Reduction in inflammation } \\
\text { marker (CRP, TNF, } \\
\text { nitrotyrosine level). Follow- } \\
\text { up: one year }\end{array}$ & $\begin{array}{l}\text { Study outcomes: MIBG imaging defect size } \\
\text { reduction was greater in ALA treated group } \\
\text { compared to placebo; ALA treated group had } \\
\text { reduction in inflammation marker compared to } \\
\text { placebo. Conclusion: ALA is beneficial }\end{array}$ \\
\hline $\begin{array}{l}\text { Yeyehd et } \\
\text { al. } 2016\end{array}$ & $\begin{array}{l}\text { Observational } \\
\text { study: } \mathrm{n}=117 \\
\text { (all TTS) }\end{array}$ & $\begin{array}{l}\text { Acute phase: Aspirin, } \\
\text { Clopidogrel, Fondaparinux, } \\
\text { Statin, beta-blockers, } \\
\text { ACE/ARB. Discharge: } \\
\text { ACE/ARB, beta-blockers, } \\
\text { aspirin, clopidogrel, statin + } \\
\text { psychological management }\end{array}$ & $\begin{array}{l}\text { Outcome measures: in- } \\
\text { hospital mortality; one-year } \\
\text { hospital readmission; } \\
\text { recurrence of TTS. Follow- } \\
\text { up: one year }\end{array}$ & $\begin{array}{l}\text { Study outcomes: no in-hospital mortality; } 2.8 \% \text { re- } \\
\text { hospitalization with heart failure; no recurrence of } \\
\text { TTS. Conclusion: the standard regime is beneficial, } \\
\text { consider discontinued antiplatelet at discharge if } \\
\text { TTS diagnosis is certain }\end{array}$ \\
\hline $\begin{array}{l}\text { Ansari et } \\
\text { al. } 2018\end{array}$ & $\begin{array}{l}\text { Observational } \\
\text { study: } \mathrm{n}=114 \\
\text { TTS with } \\
\text { hemodynamic } \\
\text { instability }\end{array}$ & $\begin{array}{l}\text { With or without } \\
\text { catecholamine support in- } \\
\text { hospital }\end{array}$ & $\begin{array}{l}\text { Outcome measures: in- } \\
\text { hospital mortality; long-term } \\
\text { mortality. Follow-up: Four } \\
\text { years }\end{array}$ & $\begin{array}{l}\text { Study outcomes: patients require catecholamine } \\
\text { support higher in-hospital and long-term mortality; } \\
\text { higher } 30 \text { day and long-term mortality. Conclusion: } \\
\text { catecholamine use for circulatory support possibly } \\
\text { exacerbates the risk of mortality }\end{array}$ \\
\hline $\begin{array}{l}\text { Santoro et } \\
\text { al. } 2016\end{array}$ & $\begin{array}{l}\text { Case- } \\
\text { controlled } \\
\text { study: } \mathrm{n}=9 \\
\text { TTS with } \\
\text { LVOTO }\end{array}$ & $\begin{array}{l}\text { IV esmolol infusion } 0.150 .3 \\
\mathrm{mg} / \mathrm{kg} / \mathrm{min} \text { for } 24 \text { hours } \\
\text { after admission, bisoprolol } \\
1.5 \mathrm{mg} \text { daily. Case- } \\
\text { controlled study: } \mathrm{n}=9 \text { TTS } \\
\text { with LVOTO }\end{array}$ & $\begin{array}{l}\text { Outcome measures: LVOT } \\
\text { pressure gradient; systolic } \\
\text { blood pressure. Follow-up: } \\
\text { nine months }\end{array}$ & $\begin{array}{l}\text { Study outcomes: esmolol infusion associated with } \\
\text { reduction LVOT gradient and systolic blood } \\
\text { pressure. Conclusion: esmolol infusion and } \\
\text { bisoprolol is possibly beneficial in TTS with LVOTO }\end{array}$ \\
\hline $\begin{array}{l}\text { Abanador- } \\
\text { Kamper et } \\
\text { al. } 2017\end{array}$ & $\begin{array}{l}\text { Observational } \\
\text { study: } \mathrm{n}=72 \\
\text { (all TTS) }\end{array}$ & $\begin{array}{l}\text { Different combination } \\
\text { antithrombotic therapy } \\
\text { (aspirin, P2Y12 antagonist, } \\
\text { OAC and LMWH) for } 3,6 \text { or } \\
12 \text { months) + Heart failure } \\
\text { regimen (ACE, beta- } \\
\text { blocker, MRA) at discharge }\end{array}$ & $\begin{array}{l}\text { Outcome measures - MACE: } \\
\text { in-hospital/ Long-term } \\
\text { mortality, stroke, myocardial } \\
\text { infarction, recurrent TTS. } \\
\text { Follow-up: } 24 \text { months }\end{array}$ & $\begin{array}{l}\text { Study outcomes: moderate MACE, an event rate of } \\
12 \%, 1 \% \text { in-hospital mortality, } 5 \% \text { two-year all- } \\
\text { cause mortality. Conclusion: beneficial } \\
\text { antithrombotic therapy + heart failure regime for at } \\
\text { least two months }\end{array}$ \\
\hline $\begin{array}{l}\text { Isogai et al. } \\
2016\end{array}$ & $\begin{array}{l}\text { Observational } \\
\text { study: } \\
\mathrm{n}=2,672 \text { (all } \\
\text { TTS) }\end{array}$ & $\begin{array}{l}\text { Early beta-blockers use } \\
\text { who started on day one or } \\
\text { two of hospitalization } \\
\text { compared to no beta- } \\
\text { blocker treatment during } \\
\text { hospitalization (control }\end{array}$ & $\begin{array}{l}\text { Outcome measure: } 30 \text {-day } \\
\text { in-hospital mortality. Follow- } \\
\text { up: in-hospital until 30-day } \\
\text { after admission }\end{array}$ & $\begin{array}{l}\text { Study outcomes: no mortality benefit for early beta- } \\
\text { blocker using compared to control group. } \\
\text { Conclusion: early beta-blocker not beneficial }\end{array}$ \\
\hline
\end{tabular}




\section{Cureus}

\begin{tabular}{|c|c|c|c|c|}
\hline \multicolumn{5}{|c|}{ group) } \\
\hline $\begin{array}{l}\text { Francesco } \\
\text { et al. } 2014\end{array}$ & $\begin{array}{l}\text { Meta- } \\
\text { analysis: } \mathrm{n}=8 \\
\text { studies (all } \\
\text { TTS studies } \\
\text { with a median } \\
\text { follow up of } \\
\text { three years) }\end{array}$ & $\begin{array}{l}\text { Standard pharmacological } \\
\text { therapy (beta-blockers, } \\
\text { ACE/ARB, aspirin. and } \\
\text { statins) }\end{array}$ & $\begin{array}{l}\text { Outcome measures: } \\
\text { recurrence of TTS at follow } \\
\text { up. Follow-up: median three } \\
\text { years }\end{array}$ & $\begin{array}{l}\text { Study outcomes: All four pharmacological therapies } \\
\text { do not significantly reduce recurrence of TTS. } \\
\text { Conclusion: beta-blockers, ACE, ARB, aspirin, and } \\
\text { statins are not beneficial in reducing recurrence of } \\
\text { TTS }\end{array}$ \\
\hline $\begin{array}{l}\text { Kumar et } \\
\text { al. } 2011\end{array}$ & $\begin{array}{l}\text { Systematic } \\
\text { review: } n=11 \\
\text { case reports } \\
\text { of TTS with } \\
\text { CR }\end{array}$ & $\begin{array}{l}\text { Use of beta-blockers of } \\
\text { patient with cardiac rupture } \\
\text { compared to control group }\end{array}$ & $\begin{array}{l}\text { Outcome measures: N/A. } \\
\text { Follow up: N/A }\end{array}$ & $\begin{array}{l}\text { Study outcomes: TTS who developed CR associated } \\
\text { with lower use of beta-blockers compared to control } \\
\text { group (mean: } 36 \% \text { vs } 86 \% \text { ), P }=.03 \text {. Conclusion: } \\
\text { beta-blocker use may have protective effect against } \\
\text { CR and may be useful in TTS patients }\end{array}$ \\
\hline $\begin{array}{l}\text { Regnante } \\
\text { et al. } 2009\end{array}$ & $\begin{array}{l}\text { Observational } \\
\text { study: } \mathrm{n}=70 \\
\text { (all TTS) }\end{array}$ & $\begin{array}{l}\text { Standard cardiovascular } \\
\text { medication (aspirin, beta- } \\
\text { blockers, ACE, statin). } \\
\text { Discharged with warfarin } \\
\text { for TTS with severe apical } \\
\text { wall motion abnormalities }\end{array}$ & $\begin{array}{l}\text { Outcome measures: MACE; } \\
\text { recurrence of TTS. Follow- } \\
\text { up: four years }\end{array}$ & $\begin{array}{l}\text { Study outcomes: long-term use of ACE before TTS } \\
\text { onset protective against cardiogenic shock, } \\
\text { sustained ventricular arrhythmia and death; beta- } \\
\text { blockers not protective against recurrence of TTS. } \\
\text { Conclusion: long-term use of ACE may be } \\
\text { beneficial/protective against TTS, beta-blockers not } \\
\text { beneficial against recurrent TTS }\end{array}$ \\
\hline $\begin{array}{l}\text { Fazzio et } \\
\text { al. } 2008\end{array}$ & $\begin{array}{l}\text { Observational } \\
\text { study: } \mathrm{n}=33 \\
\text { (all TTS) }\end{array}$ & $\begin{array}{l}\text { Beta-blockers, ACE } \\
\text { inhibitors, aspirin, or } \\
\text { calcium channel blockers } \\
\text { compared to control }\end{array}$ & $\begin{array}{l}\text { Outcome measures: LVEF } \\
\text { functional improvement; } \\
\text { days of hospitalization. } \\
\text { Follow-up: } 30 \text { days }\end{array}$ & $\begin{array}{l}\text { Study outcomes: no significant difference found } \\
\text { between treatment group and control group. } \\
\text { Conclusion: All four medications are not beneficial }\end{array}$ \\
\hline $\begin{array}{l}\text { de } \\
\text { Gregorio. } \\
2010\end{array}$ & $\begin{array}{l}\text { Systematic } \\
\text { review: } \mathrm{n}=36 \\
\text { TTS with LV } \\
\text { thrombus }\end{array}$ & Anticoagulation & $\begin{array}{l}\text { Outcome measures: any } \\
\text { cardioembolic event (stroke, } \\
\text { TIA, renal infarct, peripheral } \\
\text { ischemia). Follow-up: N/A }\end{array}$ & $\begin{array}{l}\text { Study outcome: Early anticoagulation treatment with } \\
\text { suspected TTS at risk of thromboembolic diseases, } \\
\text { irrespective for presence of LV clot. Conclusion: } \\
\text { anticoagulation is beneficial in TTS with risk of } \\
\text { thromboembolism }\end{array}$ \\
\hline $\begin{array}{l}\text { Santoro et } \\
\text { al. } 2013\end{array}$ & $\begin{array}{l}\text { Case series: } \\
n=13 \text { (all TTS) }\end{array}$ & $\begin{array}{l}\text { IV levosimendan } 0.1 \\
\mathrm{mcg} / \mathrm{kg} / \mathrm{min}\end{array}$ & $\begin{array}{l}\text { Outcome measures: LVEF; } \\
\text { any adverse event. Follow- } \\
\text { up: } 441 \text { days }\end{array}$ & $\begin{array}{l}\text { Study outcome: all had improved LVEF on third day } \\
\text { and discharge compared to admission; } 15 \% \text { had } \\
\text { adverse event. Conclusion: levosimendan possibly } \\
\text { beneficial in improving LVEF }\end{array}$ \\
\hline $\begin{array}{l}\text { Dias et al. } \\
2016\end{array}$ & $\begin{array}{l}\text { Retrospective } \\
\text { study: } \mathrm{n}=206 \\
\text { (all TTS) }\end{array}$ & $\begin{array}{l}\text { Antiplatelet (single/dual), } \\
\text { beta-blockers, ACE, or } \\
\text { statin }\end{array}$ & $\begin{array}{l}\text { Outcome measure: MACE } \\
\text { (in-hospital heart failure, } \\
\text { death, stroke or respiratory } \\
\text { failure). Follow-up: until } \\
\text { discharge }\end{array}$ & $\begin{array}{l}\text { Study outcome: single or dual antiplatelet therapy } \\
\text { independent predictors of lower incidence of MACE. } \\
\text { Conclusion: antiplatelet therapy beneficial }\end{array}$ \\
\hline $\begin{array}{l}\text { Singh et al. } \\
2014\end{array}$ & $\begin{array}{l}\text { Systematic } \\
\text { review and } \\
\text { meta- } \\
\text { analysis: } \\
\mathrm{n}=847 \text { (all } \\
\text { TTS) }\end{array}$ & Beta-blockers and ACE & $\begin{array}{l}\text { Outcome measure: } \\
\text { recurrence rate. Follow-up: } \\
\text { N/A }\end{array}$ & $\begin{array}{l}\text { Study outcome: TTS recurrence inversely correlated } \\
\text { with ACE prescription and independent of beta- } \\
\text { blockers. Conclusion: ACE beneficial }\end{array}$ \\
\hline
\end{tabular}

\section{TABLE 1: Studies included in this review regarding clinical outcomes of management of Takotsubo syndrome}

ACE, angiotensin-converting enzyme (inhibitors); ALA, alpha-lipoic acid; ARB, aldosterone receptor blocker; CR, cardiac rupture; CRP, C-reactive protein; LMWH, low molecular weight heparin; LV, left ventricular; LVEF, left ventricular ejection fraction; LVOT, left ventricular outflow tract; LVOTO, left ventricular outflow tract obstruction; MACE, major adverse cardiac event; MIBG, metaiodobenzylguanidine; MRA, mineralocorticoid receptor antagonists; N/AV, not applicable; OAC, oral anticoagulants; OD, once daily; TIA, transient ischemic attack; TNF, tumor necrosis factor; TTS, Takotsubo syndrome 


\section{Cureus}

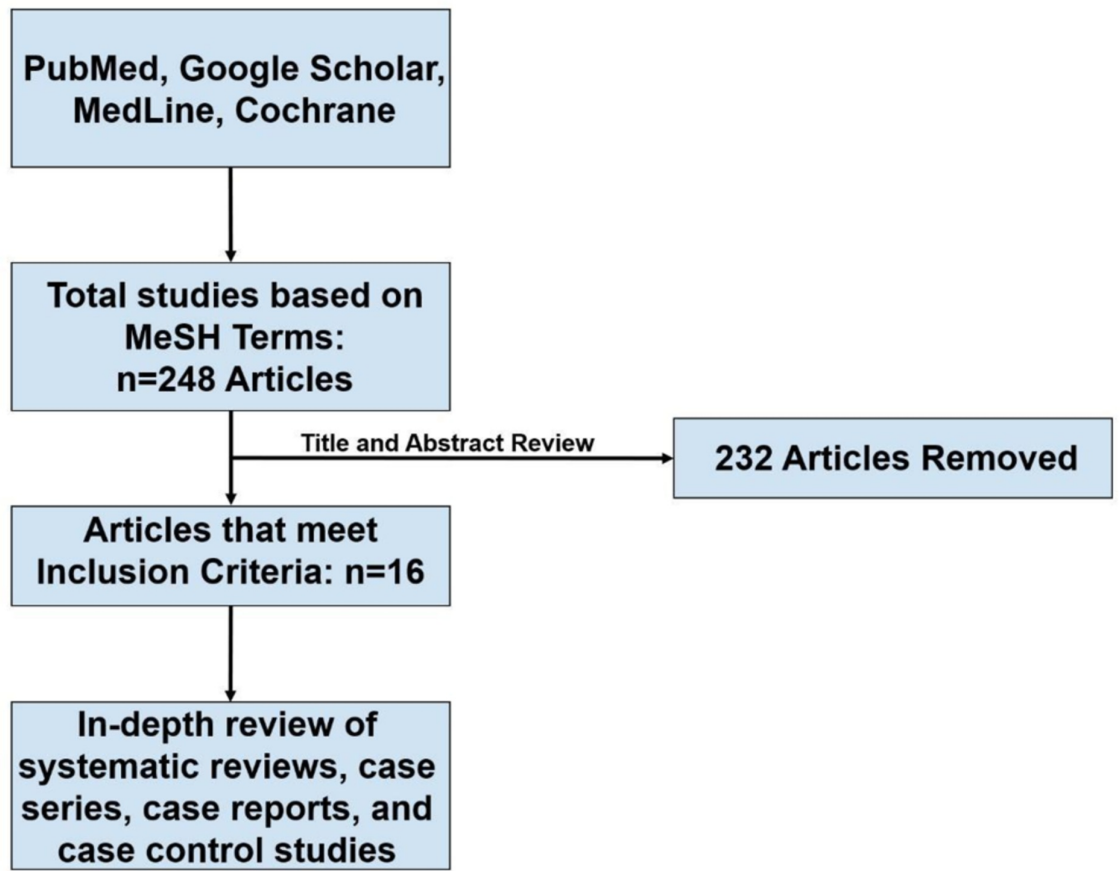

\section{FIGURE 1: The PRISMA search strategy of the review}

PRISMA, Preferred Reporting Items for Systematic Reviews and Meta-Analyses

Our review of TTS is divided into a short discussion about diagnosis and an extended discussion about management. The extended discussion is divided into TTS with and without complications.

\section{Diagnosis of TTS}

The diagnosis of TTS should be based on differentials in patients with ACS symptoms such as chest pain or dyspnea on exertion with positive cardiac biomarkers, including troponin, particularly when echocardiographic and clinical manifestations do not fit the pattern of ACS [21]. A careful history review of physical or emotional stressors should be taken. However, TTS can present without any inciting emotional or physical stressors. A diagnosis of TTS is met if the patient meets all four Mayo Clinic criteria; these can be helpful in its diagnosis (Table 2) [22-23].

\section{Mayo Criteria}

1 Transient regional LV wall dysfunction (dyskinesia, hypokinesia, and akinesia) with deficits extending beyond a single epicardial contribution; with a rare exception of focal and global type

2 New ST elevation or T-wave inversion on EKG or troponin elevation

3 Absence of angiographic evidence of plaque or coronary obstruction

4 Absence of myocarditis or pheochromocytoma

\section{TABLE 2: Mayo diagnostic criteria}

LV, left ventricular; EKG, electrocardiogram

A diagnosis of TTS should also be considered if wall motion defects do not correlate with an obstructed coronary artery. The exception is a percentage of patients that have concurrent obstructed coronary artery disease (CAD) and TTS; per the International Takotsubo Registry, this subset included 15.3\% of TTS cases [5]. Thus, a diagnosis of TTS that includes an electrocardiogram and troponin results can resemble ACS. 


\section{Cureus}

Diagnostic Imaging

Coronary angiogram is useful for diagnosing TTS. Serial LV systolic function assessment can be done with serial echocardiograms, a one-time assessment with coronary ventriculography, and then cardiac magnetic resonance imaging. It is imperative to suspect TTS during the evaluation of ACS. The approach detailed in Figure 2 should be considered for TTS diagnosis during the evaluation of ACS.

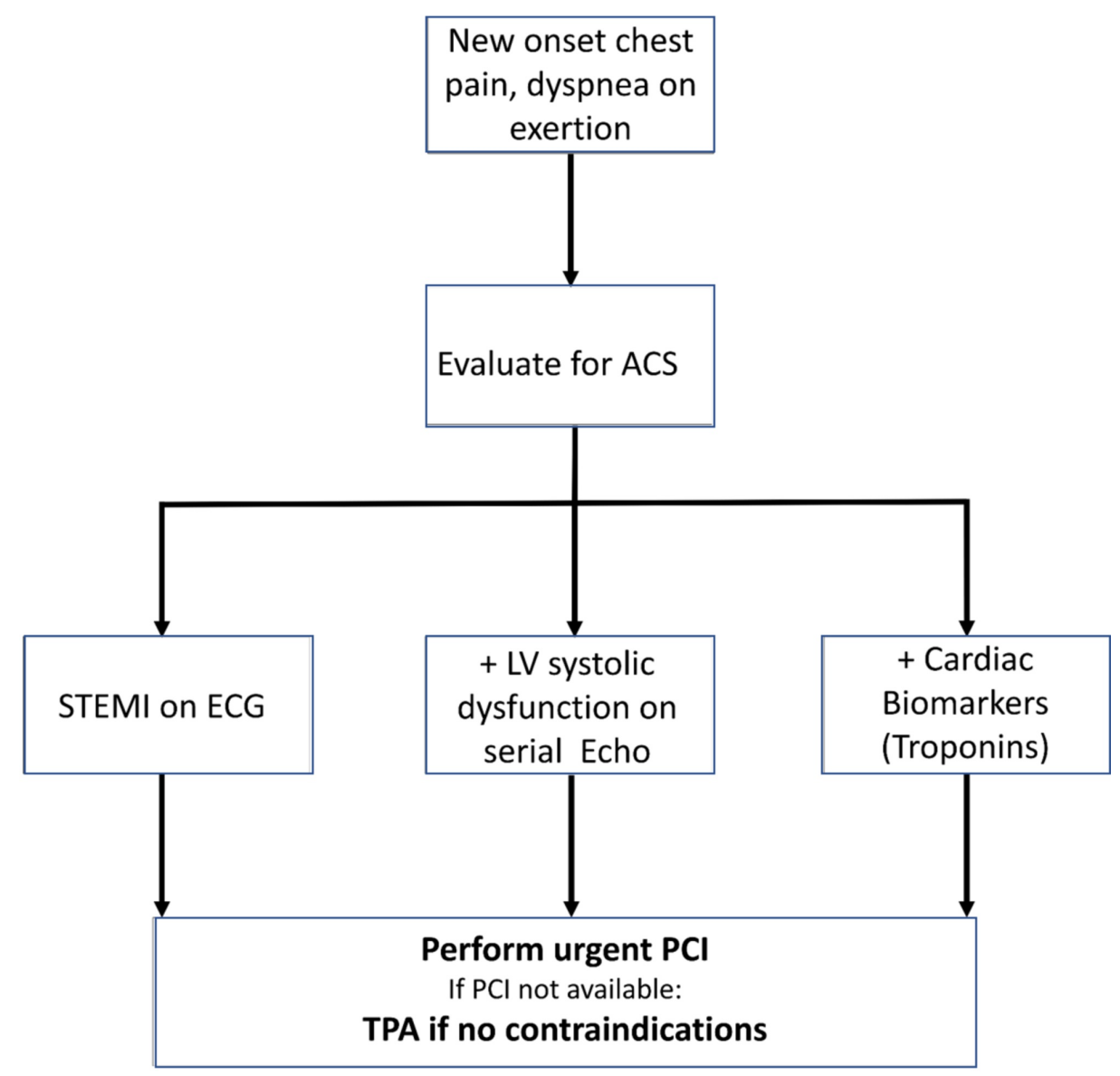

FIGURE 2: TTS diagnosis during the evaluation of ACS

ACS, acute coronary syndrome; LV, left ventricular; PCI, percutaneous coronary intervention; STEMI, STsegment elevation myocardial infarction; TPA, tissue plasminogen activator; TTS, Takotsubo syndrome

Detection of wall defects on echocardiography or LV ventriculography suggests a review of the following wall defect patterns (Table 3) [5,24-26]. 


\section{Cureus}

\begin{tabular}{ll}
\hline $\begin{array}{l}\text { Location } \\
\text { Apical }\end{array}$ & $\begin{array}{l}\text { The most common type of pattern of wall defect found in the TTS International Takotsubo Registry. There is significant LV systolic } \\
\text { apical ballooning with mid/apical hypokinesia and often basal hyperkinesia. }\end{array}$ \\
$\begin{array}{l}\text { Mid- } \\
\text { ventricular }\end{array}$ & $\begin{array}{l}\text { The second most common pattern of wall defect found in the International Takotsubo Registry. There is LV hypokinesia/wall defect } \\
\text { only in mid-ventricular region with apical sparing. }\end{array}$ \\
Basal & $\begin{array}{l}\text { The third most common type of pattern of wall defect found in the International Takotsubo Registry. There is basal hypokinesia of LV } \\
\text { with sparing of mid-ventricular and apical region. }\end{array}$ \\
Focal & $\begin{array}{l}\text { The fourth most common type of pattern of wall defect found in International Takotsubo Registry. In this type, isolated anterolateral } \\
\text { segment dysfunction of LV is found. }\end{array}$ \\
Global & In rare circumstances, TTS patients can have global hypokinesia.
\end{tabular}

\section{TABLE 3: Wall motion abnormalities in TTS}

LV, left ventricular; TTS, Takotsubo syndrome

[5], [24-26]

Cardiac Magnetic Resonance

Cardiac magnetic resonance can highlight the absence of late gadolinium enhancement in TTS as compared to the presence of late gadolinium enhancement seen in transmural or subendocardial regions in myocardial infarction [25].

\section{Management}

General Management

The management of TTS is generally conservative and focused on emotional or physical stress relief. However, in some cases, acute complications such as heart failure and shock develop, and intensive management is required. The management of heart failure and shock is similar to that in the general guidelines of their management in non-TTS cases except in the presence of LVOTO. In cases of LVOTO, caution should be taken in preventing volume depletion or with vasodilatory medications. Generally, the duration of treatment of TTS ranges from three months to one year depending on expert opinion. In a study by Fazio et al., it was found that TTS treatment of more than three months did not add any significant change to survival and should be avoided [16].

The management of TTS is divided into TTS without complications and TTS with complications. These complications include hypotension and cardiogenic shock with heart failure or LVOTO, cardiac arrhythmias, and thromboembolism.

TTS without Complications

After a comprehensive assessment, if patients are hemodynamically stable with no other signs of complications such as acute heart failure, arrhythmia, or thromboembolism, they should be admitted to cardiology for further monitoring. In a study by Yeyehd et al., the acute and post-discharge management of TTS with dual antiplatelet therapy (DAPT) including aspirin and clopidogrel, anticoagulation such as low molecular weight heparin or fondaparinux, beta-blockers, statins, angiotensin-converting enzyme (ACE) inhibitors/angiotensin receptor blockers (ARBs), and psychological stress relief management helped to lower inpatient mortality and recurrence of TTS [8]. Furthermore, a study by Yeyehd et al. indicated that DAPT should be discontinued at discharge if TTS is certain [8]. A further review also revealed a study by Dias et al. indicating that single antiplatelet therapy or DAPT are independently helpful in lowering major adverse cardiovascular events/complications in TTS patients [19]. In a study by Templin et al. ACE/ARBs were associated with improved survival at one-year follow-up in patients with and without heart failure in TTS [5]. A study by Regnante et al. showed that the use of ACE inhibitors before the onset of TTS prevented cardiogenic shock, arrhythmias, and death [15]. A meta-analysis by Santoro et al. reviewed three-year follow-up data and concluded that aspirin, statin, beta-blocker, and ACE/ARBs do not reduce the recurrence of TTS [13].

TTS with Complications - Hypotension and Cardiogenic Shock 
For TTS patients with hypotension or shock, continuous monitoring of clinical parameters such as vital signs, mental status, urine output, and renal function should be done along with telemonitoring. Up to 5\%$10 \%$ of patients with TTS can develop cardiogenic shock [5,27]. A variety of factors are associated with cardiogenic shock in TTS, including physical triggers, young age, and low LV ejection fraction. Mortality is higher in TTS with shock by roughly 10 -fold [28,29]. A clinical discordance is found between shock and systolic function of the left or right ventricle. This discordance can be due to the presence of LVOTO [30-33]. An urgent echocardiogram should be done in TTS with cardiogenic shock to look for LVOTO and to rule out the systolic anterior motion of the mitral valve or mitral regurgitation [31,33].

The management of hypotension or cardiogenic shock can be further divided into cases with and without LVOTO as follows.

Cardiogenic shock without LVOTO: In patients with hypotension without pulmonary congestion, cautious fluid resuscitation can be performed, even in patients with or without LVOTO. In patients with LV systolic dysfunction but without LVOTO, a trial of inotropic agents such as dopamine or dobutamine can serve as a temporary measure; however, an inotropic agent can cause mild LVOTO in these patients [34]. In moderate to severe LVOTO, pressor/inotropic agents are contraindicated. Patients with persistent hypotension or any signs of end-organ damage should be closely monitoring with pulmonary catheterization/wedge pressure and intra-aortic balloon pumps (IABP). This subset of patients requires vasopressors.

Cardiogenic shock with LVOTO: In patients with cardiogenic shock with moderate to severe LVOTO, inotropic agents should not be used because they can increase the degree of obstruction [31,34]. In a study by Ansari et al., it was reported that inotropes such as epinephrine, norepinephrine, dobutamine, and dopamine should be avoided in TTS, and that catecholamine excess can increase 30-day and long-term mortality in TTS [9]. Only Marfella et al. reported that alpha-adrenergic stimulation by alpha-lipoic therapy could increase sympathetic stimulation of the heart and show improvement of cardiac defects on 123Imetaiodobenzylguanidine myocardial scintigraphy at a 12-month follow-up in TTS patients [7].

The recommended treatment of TTS with moderate to severe LVOTO is similar to hypertrophic cardiomyopathy. The management of this subset of patients includes fluid resuscitation in the absence of pulmonary congestion [22,31]. The use of beta-blockers also plays a role in the relief of obstruction. A casecontrol study by Santoro et al. suggested that intravenous administration of esmolol at admission, followed by daily bisoprolol can improve LVOTO gradient and relieve obstruction [10].

In TTS with severe LVOTO, alpha agonists such as phenylephrine can help in a closely monitored setting by increasing afterload. However, phenylephrine should be used with caution as it can cause coronary vasospasm. Patients with severe/persistent hypotension not responsive to fluid resuscitation or initial measure with an intra-aortic balloon pump should be closely monitored. As IABPs can decrease afterload, this effect should be monitored closely [32,34]. A further literature review showed several case reports that demonstrated the efficacy of extracorporeal membrane oxygenation as a life-saving alternative treatment for circulatory support in TTS patients with cardiogenic shock [35-37].

TTS with Complications - Heart Failure

Acute heart failure (HF) in TTS is managed the same way as HF from any other illness: by oxygen, respiratory support as needed, and preload and afterload reduction. The exception to the regular management is that preload and afterload reduction therapies should be avoided in cases with LVOTO. In TTS patients with HF without LVOTO, the standard cocktail of medications for HF can be prescribed. This includes diuretics, ACE inhibitors, or ARBs [22]. Beta-blockers do not lower mortality in HF due to TTS. In an observational study of 2,672 patients by Isogai et al., beta-blockers were unable to lower 30-day in-patient mortality in 423 patients [12]. A beneficial effect of beta-blockers is a low incidence of cardiac rupture in TTS treated with betablocker, as reported by Kumar et al. [14]. A meta-analysis by Singh et al. concluded that ACE inhibitors prevent the recurrence of TTS, while beta-blockers do not [20].

The recommended duration of treatment is not well known, but in general, treatment with HF medication is four weeks until systolic function improves. A Mayo clinic study failed to show any survival benefits of ACE inhibitors and beta-blockers in TTS patients [38]. An observation study by Abanador-Kamper et al. reviewed all the treatment regimens for TTS patients and concluded that the benefits of heart failure cocktail medications and antithrombotic therapy is highest during the first two months of TTS, with a low side effect profile, high survival, and early recovery [11]. A case series study by Santoro et al. concluded that the use of levosimendan can improve the LV ejection fraction and has a good safety profile [18].

TTS with Complications - Thromboembolism

Ventricular thrombus is found in $1.3 \%$ of the 1,750 TTS patients in the International Takotsubo Registry [5]. The risk of LV thrombus should be evaluated by echocardiography in TTS patients with severe LV dysfunction. There are no clear guidelines for anticoagulation to prevent LV thrombus, but some reports have shown that 10 days of anticoagulation can reduce the incidence of LV thrombus in TTS patients. In 
patients with severe LV dysfunction and/or with LV thrombus, anticoagulation for three months until resolution of LV dysfunction to prevent systemic embolization is preferred [22-23]. A systematic review by de Gregorio found that early anticoagulation is beneficial in TTS in patients with or without thromboembolism [17]. This is also supported by an observational study by Santoro et al. that found that early heparin administration followed by warfarin for three months prevented stroke in TTS patients with and without LV thrombus [6].

\section{Conclusions}

In conclusion, we have reviewed the most recent observational studies and clinical trials to summarize the management of TTS. The initial management should include optimal medical therapy with antiplatelet medications, statins, beta-blockers, and ACE/ARBs. Pressor medications are contraindicated in TTS with LVOTO. In TTS with thromboembolism, heparin with warfarin should be continued for at least three months.

\section{Additional Information \\ Disclosures}

Conflicts of interest: In compliance with the ICMJE uniform disclosure form, all authors declare the following: Payment/services info: All authors have declared that no financial support was received from any organization for the submitted work. Financial relationships: All authors have declared that they have no financial relationships at present or within the previous three years with any organizations that might have an interest in the submitted work. Other relationships: All authors have declared that there are no other relationships or activities that could appear to have influenced the submitted work.

\section{References}

1. Lüscher TF, Templin C: Is Takotsubo syndrome a microvascular acute coronary syndrome? Towards of a new definition. Eur Heart J. 2016, 37:2816-20. 10.1093/eurheartj/ehw057

2. Deshmukh A, Kumar G, Pant S, Rihal C, Murugiah K, Mehta JL: Prevalence of Takotsubo cardiomyopathy in the United States. Am Heart J. 2012, 164:66-71. 10.1016/j.ahj.2012.03.020

3. Showkathali R, Patel H, Ramoutar A, et al.: Typical Takotsubo cardiomyopathy in suspected ST elevation myocardial infarction patients admitted for primary percutaneous coronary intervention. Eur J Intern Med. 2014, 25:132-6. 10.1016/j.ejim.2013.09.004

4. Prasad A, Dangas G, Srinivasan M, Yu J, Gersh BJ, Mehran R, Stone GW: Incidence and angiographic characteristics of patients with apical ballooning syndrome (Takotsubo/stress cardiomyopathy) in the HORIZONS-AMI trial. Catheter Cardiovasc Interv. 2014, 83:343-8. 10.1002/ccd.23441

5. Templin C, Ghadri JR, Diekmann J, et al.: Clinical features and outcomes of Takotsubo (stress) cardiomyopathy. N Engl J Med. 2015, 373:929-38. 10.1056/NEJMoa1406761

6. Santoro F, Stiermaier T, Tarantino N, et al.: Left ventricular thrombi in Takotsubo syndrome: incidence, predictors, and management: results from the GEIST (German Italian Stress Cardiomyopathy) registry. J Am Heart Assoc. 2017, 6:006990. 10.1161/JAHA.117.006990

7. Marfella R, Barbieri M, Sardu C, et al.: Effects of $\alpha$-lipoic acid therapy on sympathetic heart innervation in patients with previous experience of transient Takotsubo cardiomyopathy. J Cardiol. 2016, 67:153-61. 10.1016/j.jjcc.2015.07.012

8. Yayehd K, N'da NW, Belle L, et al.: Management of Takotsubo cardiomyopathy in non-academic hospitals in France: the observational French syndromes of Takotsubo (OFSETT) study. Arch Cardiovasc Dis. 2016, 109:4-12. 10.1016/j.acvd.2015.08.004

9. Ansari U, El-Battrawy I, Fastner C, et al.: Clinical outcomes associated with catecholamine use in patients diagnosed with Takotsubo cardiomyopathy. BMC Cardiovasc Disord. 2018, 18:54. 10.1186/s12872-018-07846

10. Santoro F, Ieva R, Ferraretti A, et al.: Hemodynamic effects, safety, and feasibility of intravenous esmolol infusion during Takotsubo cardiomyopathy with left ventricular outflow tract obstruction: results from a multicenter registry. Cardiovasc Ther. 2016, 34:161-6. 10.1111/1755-5922.12182

11. Abanador-Kamper N, Kamper L, Wolfertz J, Pomjanski W, Wolf-Pütz A, Seyfarth M: Evaluation of therapy management and outcome in Takotsubo syndrome. BMC Cardiovasc Disord. 2017, 17:225. 10.1186/s12872017-0661-8

12. Isogai T, Matsui H, Tanaka H, Fushimi K, Yasunaga H: Early $\beta$-blocker use and in-hospital mortality in patients with Takotsubo cardiomyopathy. Heart. 2016, 102:1029-35. 10.1136/heartjnl-2015-308712

13. Santoro F, Ieva R, Musaico F, et al.: Lack of efficacy of drug therapy in preventing Takotsubo cardiomyopathy recurrence: a meta-analysis. Clin Cardiol. 2014, 37:434-9. 10.1002/clc.22280

14. Kumar S, Kaushik S, Nautiyal A, Choudhary SK, Kayastha BL, Mostow N, Lazar JM: Cardiac rupture in Takotsubo cardiomyopathy: a systematic review. Clin Cardiol. 2011, 34:672-6. 10.1002/clc.20957

15. Regnante RA, Zuzek RW, Weinsier SB, Latif SR, Linsky RA, Ahmed HN, Sadiq I: Clinical characteristics and four-year outcomes of patients in the Rhode Island takotsubo cardiomyopathy registry. Am J Cardiol. 2009, 103:1015-9. 10.1016/j.amjcard.2008.12.020

16. Fazio G, Pizzuto C, Barbaro G, et al.: Chronic pharmacological treatment in Takotsubo cardiomyopathy. Int J Cardiol. 2008, 127:121-3. 10.1016/j.ijcard.2007.04.013

17. de Gregorio C: Cardioembolic outcomes in stress-related cardiomyopathy complicated by ventricular thrombus: a systematic review of 26 clinical studies. Int J Cardiol. 2010, 141:11-7. 10.1016/j.ijcard.2009.09.468

18. Santoro F, Ieva R, Ferraretti A, et al.: Safety and feasibility of levosimendan administration in Takotsubo 
cardiomyopathy: a case series. Cardiovasc Ther. 2013, 31:133-7. 10.1111/1755-5922.12047

19. Dias A, Franco E, Koshkelashvili N, Bhalla V, Pressman GS, Hebert K, Figueredo VM: Antiplatelet therapy in Takotsubo cardiomyopathy: does it improve cardiovascular outcomes during index event?. Heart Vessels. 2016, 31:1285-90. 10.1007/s00380-015-0729-2

20. Singh K, Carson K, Usmani Z, Sawhney G, Shah R, Horowitz J: Systematic review and meta-analysis of incidence and correlates of recurrence of Takotsubo cardiomyopathy. Int J Cardiol. 2014, 174:696-701. 10.1016/j.ijcard.2014.04.221

21. Dec GW: Recognition of the apical ballooning syndrome in the United States . Circulation. 2005, 111:388-90. 10.1161/01.CIR.0000155234.69439.E4

22. Bybee KA, Kara T, Prasad A, Lerman A, Barsness GW, Wright RS, Rihal CS: Systematic review: transient left ventricular apical ballooning: a syndrome that mimics ST-segment elevation myocardial infarction. Ann Intern Med. 2004, 141:858. 10.7326/0003-4819-141-11-200412070-00010

23. Prasad A, Lerman A, Rihal CS: Apical ballooning syndrome (Takotsubo or stress cardiomyopathy): a mimic of acute myocardial infarction. Am Heart J. 2008, 155:408-17. 10.1016/j.ahj.2007.11.008

24. Kurowski V, Kaiser A, von Hof K, et al.: Apical and midventricular transient left ventricular dysfunction syndrome (Takotsubo cardiomyopathy) frequency, mechanisms, and prognosis. Chest. 2007, 132:809-16. 10.1378/chest.07-0608

25. Eitel I, von Knobelsdorff-Brenkenhoff F, Bernhardt P, et al.: Clinical characteristics and cardiovascular magnetic resonance findings in stress (Takotsubo) cardiomyopathy. JAMA. 2011, 306:277-86. 10.1001/jama.2011.992

26. Win CM, Pathak A, Guglin M: Not Takotsubo: a different form of stress-induced cardiomyopathy - a case series. Congest Hear Fail. 2011, 17:38-41. 10.1111/j.1751-7133.2010.00195.x

27. Zalewska-Adamiec M, Bachorzewska-Gajewska H, Tomaszuk-Kazberuk A, et al.: Takotsubo cardiomyopathy: serious early complications and two-year mortality - a 101 case study. Netherlands Hear J. 2016, 24:511-9. 10.1007/s12471-016-0857-z

28. Di Vece D, Citro R, Cammann VL, et al.: Outcomes associated with cardiogenic shock in Takotsubo syndrome. Circulation. 2019, 139:413-5. 10.1161/CIRCULATIONAHA.118.036164

29. Almendro-Delia M, Núñez-Gil IJ, Lobo M, et al.: Short- and long-term prognostic relevance of cardiogenic shock in Takotsubo syndrome. JACC Hear Fail. 2018, 6:928-36. 10.1016/j.jchf.2018.05.015

30. Chong C-R, Neil CJ, Nguyen TH, Stansborough J, Law GW, Singh K, Horowitz JD: Dissociation between severity of Takotsubo cardiomyopathy and presentation with shock or hypotension. Clin Cardiol. 2013, 36:401-6. 10.1002/clc.22129

31. Villareal RP, Achari A, Wilansky S, Wilson JM: Anteroapical stunning and left ventricular outflow tract obstruction. Mayo Clin Proc. 2001, 76:79-83. 10.4065/76.1.79

32. De Backer O, Debonnaire P, Gevaert S, Missault L, Gheeraert P, Muyldermans L: Prevalence, associated factors and management implications of left ventricular outflow tract obstruction in Takotsubo cardiomyopathy: a two-year, two-center experience. BMC Cardiovasc Disord. 2014, 14:147. 10.1186/14712261-14-147

33. De Backer O, Debonnaire P, Muyldermans L, Missault L: Tako-tsubo cardiomyopathy with left ventricular outflow tract (LVOT) obstruction: case report and review of the literature. Acta Clin Belg. 2011, 66:298-301.

34. Sharkey SW, Lesser JR, Zenovich AG, Maron MS, Lindberg J, Longe TF, Maron BJ: Acute and reversible cardiomyopathy provoked by stress in women from the United States. Circulation. 2005, 111:472-9. 10.1161/01.CIR.0000153801.51470.EB

35. Dandel M, Hetzer R: Deleterious effects of catecholamine administration in acute heart failure caused by unrecognized Takotsubo cardiomyopathy. BMC Cardiovasc Disord. 2018, 18:144. 10.1186/s12872-018-08825

36. Donker DW, Pragt E, Weerwind PW, Holtkamp JWM, Vainer J, Mochtar B, Maessen JG: Rescue extracorporeal life support as a bridge to reflection in fulminant stress-induced cardiomyopathy. Int J Cardiol. 2012, 154:54-6. 10.1016/j.ijcard.2011.06.037

37. Bonacchi M, Maiani M, Harmelin G, Sani G: Intractable cardiogenic shock in stress cardiomyopathy with left ventricular outflow tract obstruction: is extra-corporeal life support the best treatment?. Eur J Heart Fail. 2009, 11:721-7. 10.1093/eurjhf/hfp068

38. Kim H, Senecal C, Lewis B, Prasad A, Rajiv G, Lerman LO, Lerman A: Natural history and predictors of mortality of patients with Takotsubo syndrome. Int J Cardiol. 2018, 267:22-7. 10.1016/j.ijcard.2018.04.139 